Everett M. Hansen

Oregon State University, Corvallis

Donald J. Goheen

USDA Forest Service, Central Point, OR

Erik S. Jules

Humboldt State University, Arcata, CA

Barbara Ullian

Siskiyou Regional Education Project, Grants Pass, OR

\title{
Managing Port-Orford-Cedar and the Introduced Pathogen Phytophthora lateralis
}

We don't know where Phytophthora lateralis came from, but since the 1920s it has been killing Port-Orford-cedar (POC) trees in the Pacific Northwest. The pathogen has spread throughout the native range of its host with dramatic ecological and economic consequences, and losses continue. Federal land management agencies have responded with a multifaceted program of disease management and research. Spread of the pathogen, the resulting loss of cedar, and the federal response to it, have become touchstones for environmental activism, triggering continuing administrative appeals and lawsuits. Now renewed energy, new research, and environmental vigilance offer hope for reversing the decline of a valuable tree.

\section{Hosts}

Chamaecyparis lawsoniana (Port-Orford-cedar or Lawson's cypress) is the largest member of the Cypress family (Fig. 1 ) and is native only to the coniferous forests of southwestern Oregon and northern California (Fig. 2) (16). Although its distribution within this limited range is often localized, POC occurs in many different environments from sea level to $2,100 \mathrm{~m}$ $(8,16)$. POC tolerates high concentrations of heavy metals in the ultramafic (including serpentine) soils scattered throughout the region and increases calcium availability in stands where it grows (7). It is commonly found in association with many rare

Dr. Hansen's address is: Department of Botany and Plant Pathology, Oregon State University, Corvallis 97331; E-mail: hansene@cgrb.orst.edu

Publication no. D-1999-1108-01F

(C) 2000 The American Phytopathological Society plant species on these sites (Fig. 3) (9). With the exception of the northern part of its range, POC usually grows primarily along streams and in areas with year-round seepage. It often grows within the active stream channel, where, as large, old trees, POC provides shade and long-lasting stream structure (Fig. 4). The stabilizing effects of its fibrous root system have also been noted by stream ecologists and fisheries biologists.

POC reproduces effectively beneath all but the most dense overstories and grows

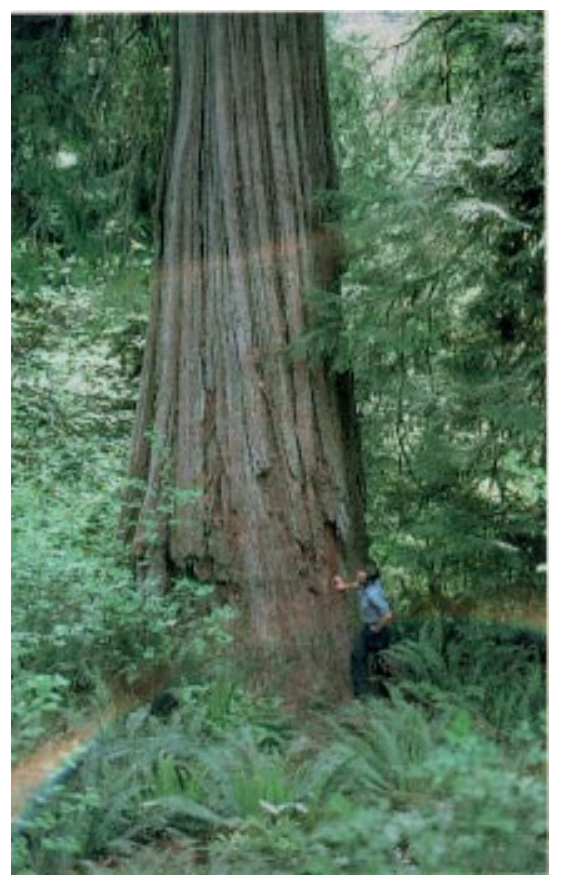

Fig. 1. Old-growth Port-Orford-cedar, Powers District, Siskiyou National Forest, Oregon. more slowly on most sites than associated conifers. With the development of thick, fibrous bark, large cedars become fire tolerant. This characteristic and its resistance to decay following injury give POC importance in fire-disturbed ecosystems (8).

The wood of POC is one of the most valuable commercially harvested conifer timbers in the world, regularly commanding a price 10 times that of Douglas-fir from the same sites. Traditionally, POC was valued for straight grain and decay

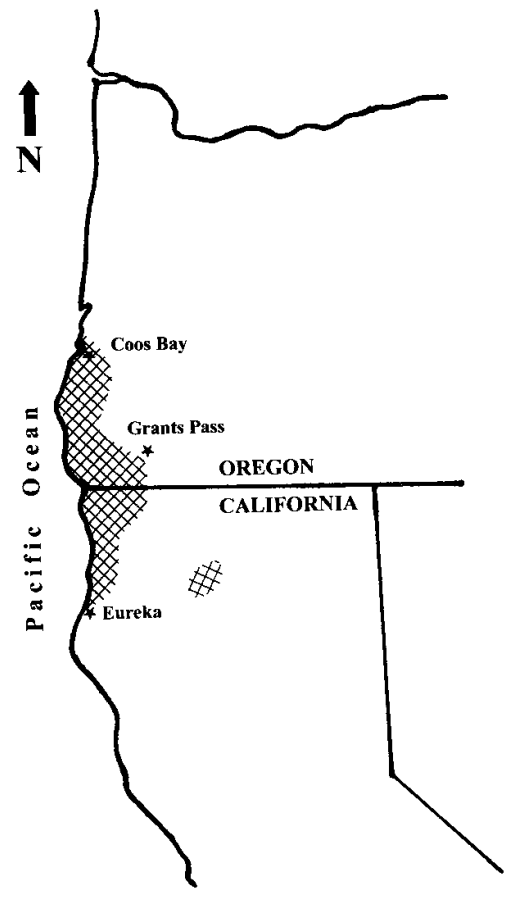

Fig. 2. Range of Port-Orford-cedar in southwestern Oregon and northern California. 
resistance in products such as boat hulls, venetian blinds, battery separators, and arrow shafts. These markets have largely been taken by substitute materials, and the value of the tree in recent decades has been determined by the export market to Japan and neighboring countries. The Japanese prize the close rings, straight grain, and white color of old-growth POC. It is used as a substitute for the Japanese hinoki (Chamaecyparis obtusa) in traditional construction and in the reconstruction of temples and shrines. POC is the only conifer that can be exported as raw logs from federal forests in the United States. At the height of the export market, harvest volumes exceeded 40 million board feet annually, and POC sold for up to $\$ 6,000$ per thousand board feet, on the stump. Today, very little cedar is exported because of changes in demand from Japan and new directions in forest management in the national forests where most cedar grows. POC was also an important species in the ornamental nursery industry. Some 200 cultivars were named, mostly by European collectors and growers. Nurseries in Oregon and Washington propagated many of these cultivars and shipped them widely. The disease has now largely eliminated POC in the American commercial trade.

Pacific yew (Taxus brevifolia) was first reported as a host of $P$. lateralis in 1991 (1) (Fig. 5). Pacific yew is a forest tree native to the Pacific Northwest and regions of the Rocky Mountains. This gymnosperm grows as a short, often bushy tree in the understory of western coniferous forests. It provides food and cover for wildlife, shades stream bottoms, and contributes to

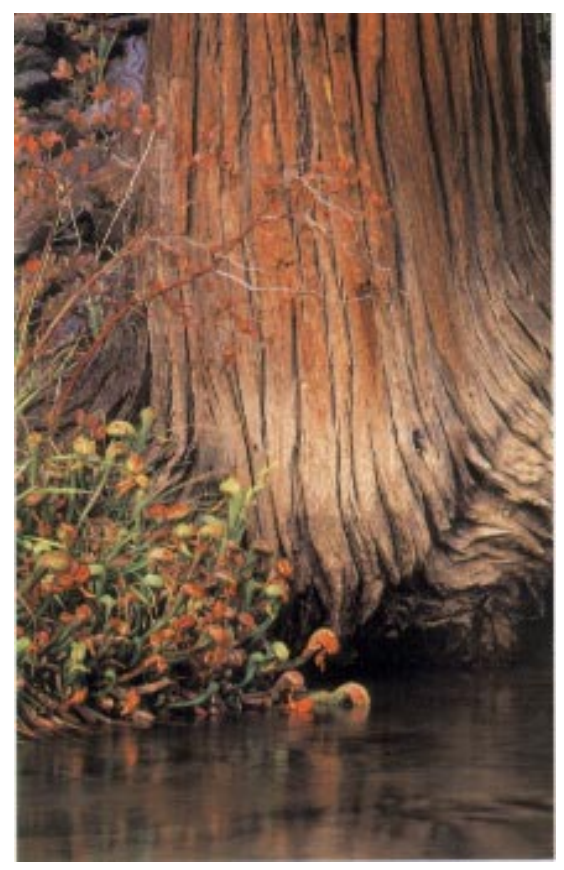

Fig. 3. Port-Orford-cedar and Darlingtonia, a rare insectivorous plant, growing in a bog. stream channel stabilization through its fibrous root system. Wood of the Pacific yew was valued by Native Americans for making tools and hunting implements, and it is valued today for ornamental woodworking (6). Pacific yew gained shortlived fame after a report that taxol, a chemical extracted from its bark, had antitumor activity in humans (15). For several years this tree was heavily harvested on state and federal lands for taxol extraction. The exploitation of this species eventually led to the need for a federal environmental impact statement, completed in September 1993. Taxol can currently be synthesized (11), reducing the economic demands on Pacific yew.

While yew is a host for P. lateralis, it is less susceptible than POC (10). Mortality of inoculated seedlings averaged $72 \%$ for

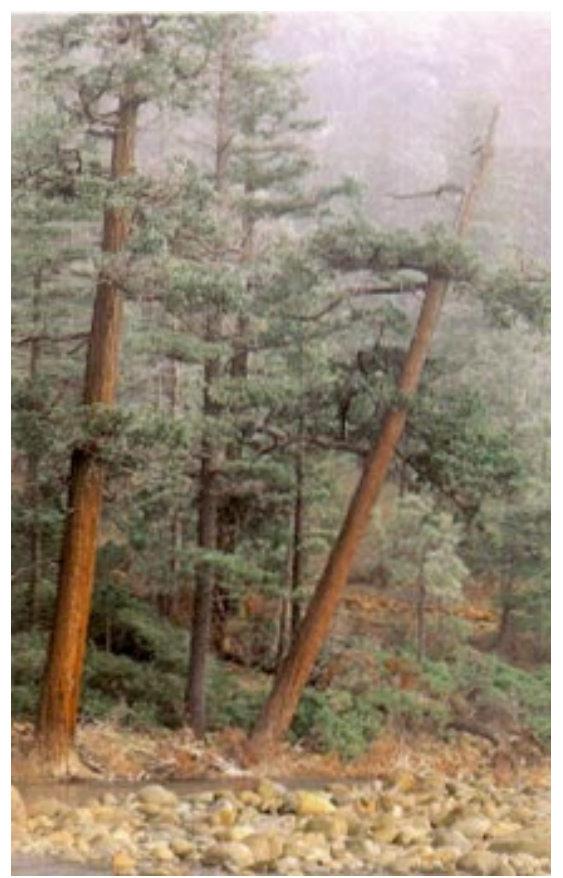

Fig. 4. Mature Port-Orford-cedar growing in a stream channel. cedar and $4 \%$ for yew, and root colonization was significantly greater in cedar seedlings than in yew seedlings. Zoospore aggregation was abundant on cedar rootlets along the zone of elongation and the region of maturation, but fewer zoospores encysted on yew rootlets. A limited field survey in southwestern Oregon and northwestern California found yew killed by $P$. lateralis only where it was growing along streams in close association with dead and dying POC. In the streamside survey, $46 \%$ of the cedar was dead, compared with $10 \%$ of the yew (Table 1).

\section{Pathogen}

Phytophthora ("plant killer") is a genus of plant pathogenic Oomycetes with swim-

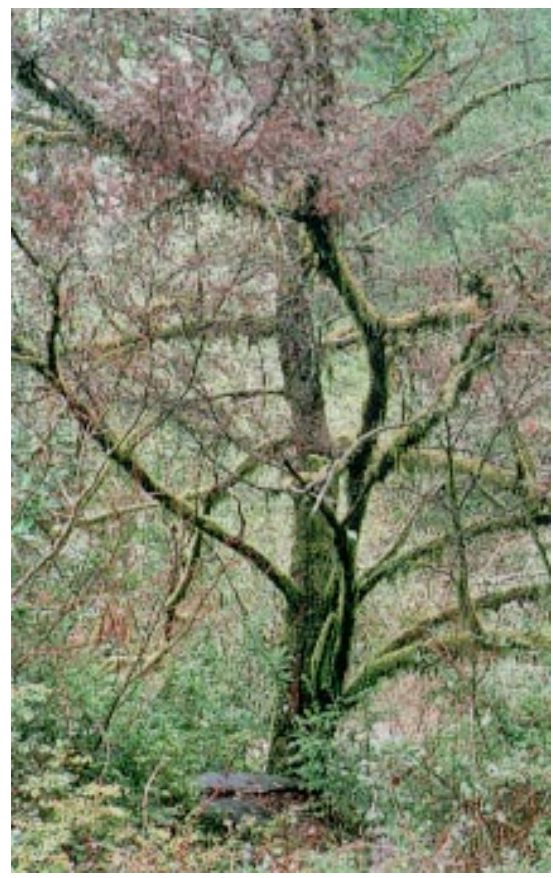

Fig. 5. Pacific yew killed by Phytophthora lateralis on the Six Rivers National Forest, California. Note stump of previously killed cedar in front of the dead yew.

Table 1. Mortality of Port-Orford-cedar and Pacific yew caused by Phytophthora lateralis within $9 \mathrm{~m}$ of three streams in southwestern Oregon and northern California

\begin{tabular}{|c|c|c|c|c|}
\hline \multirow[b]{2}{*}{ Size class } & \multicolumn{2}{|c|}{ Port-Orford-cedar } & \multicolumn{2}{|c|}{ Pacific yew } \\
\hline & Total & Dead $(\%)$ & Total & Dead $(\%)$ \\
\hline \multicolumn{5}{|c|}{ Middle fork of Smith River } \\
\hline$\leq 12 \mathrm{~cm} \mathrm{DBH}^{\mathrm{a}}$ & 391 & $50(13)$ & 324 & $32(10)$ \\
\hline$>12 \mathrm{~cm} \mathrm{DBH}$ & 504 & 199 (39) & 74 & $13(18)$ \\
\hline Total & 895 & $249(28)$ & 398 & $45(11)$ \\
\hline \multicolumn{5}{|l|}{ Coon Creek } \\
\hline$\leq 12 \mathrm{~cm} \mathrm{DBH}$ & 485 & $236(48)$ & 47 & $15(32)$ \\
\hline$>12 \mathrm{~cm} \mathrm{DBH}$ & 344 & $305(89)$ & 4 & $1(25)$ \\
\hline Total & 829 & $541(65)$ & 51 & $16(31)$ \\
\hline \multicolumn{5}{|l|}{ Elder Creek } \\
\hline$\leq 12 \mathrm{~cm} \mathrm{DBH}$ & 421 & $133(32)$ & 342 & $23(7)$ \\
\hline$>12 \mathrm{~cm} \mathrm{DBH}$ & 441 & $276(62)$ & 46 & $2(4)$ \\
\hline Total & 862 & 409 (47) & 388 & $25(6)$ \\
\hline
\end{tabular}

$\overline{\text { a }}$ Diameter at breast height. 
ming zoospores and thick-walled resting spores, the oospores and chlamydospores (Fig. 6). P. lateralis is distinguished from other Phytophthora species most readily by its pathogenicity to C. lawsoniana and $T$. brevifolia. It was known only from the west coast of North America, but was recently identified in France on a containergrown POC from a commercial nursery (5). The latter report, probably resulting from a recent introduction on ornamental stock from North America, is the only confirmation of its presence outside North America. Erwin and Ribeiro (2) suggested a French origin for the disease, but this interpretation is not supported by available records in France or the United States.

While the origins of $P$. lateralis are unknown, it is clearly not native to the natu- ral range of POC. The nearly complete susceptibility of its primary host marks it as an introduced pathogen. It is well suited to the forests of the cedar region, favoring cool wet spring, fall, and winter conditions for growth and reproduction, and surviving the hot, dry summers as chlamydospores formed laterally on the hyphae (hence the Latin name). It is carried uphill and between watersheds in mud on vehicles and equipment. Wildlife and cattle, as well as hikers and woods workers, may also transport the pathogen. Once introduced into a watershed, it moves downhill in running water, primarily along stream courses, attacking and killing any POC encountered.

The disease was first reported in 1923 near Seattle in nurseries growing POC for

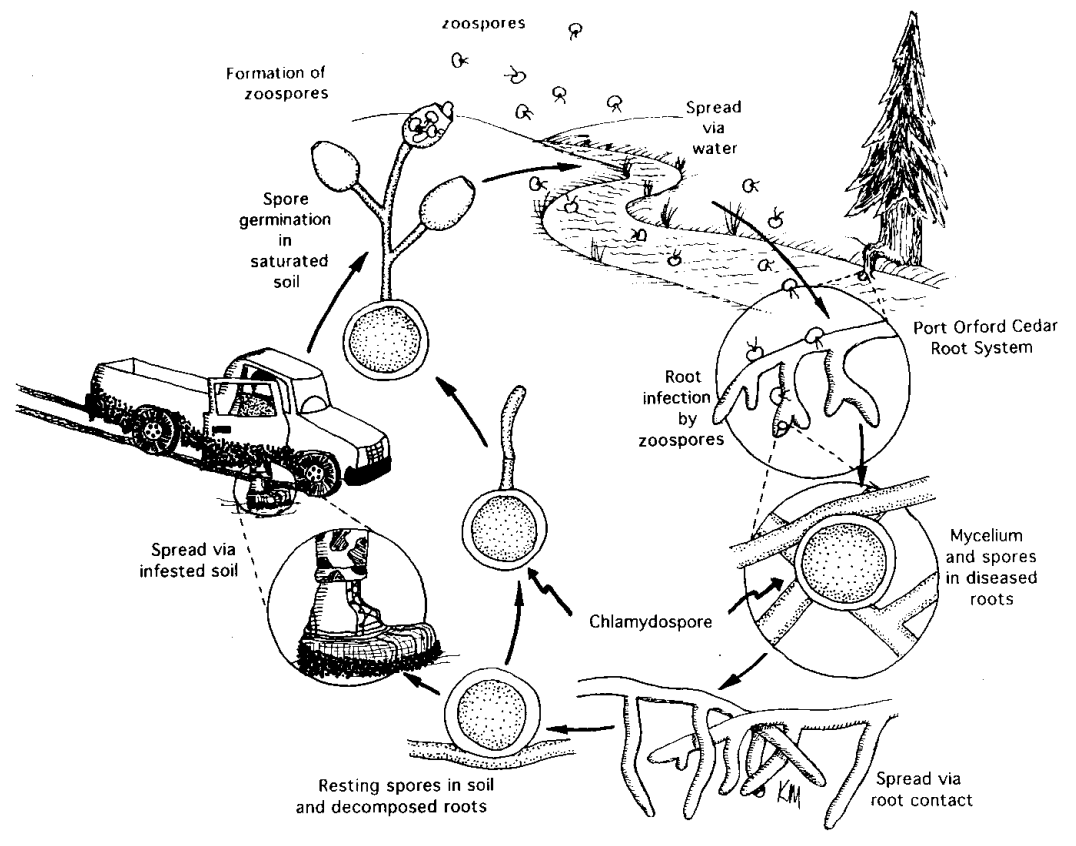

Fig. 6. Disease cycle of Phytophthora lateralis.

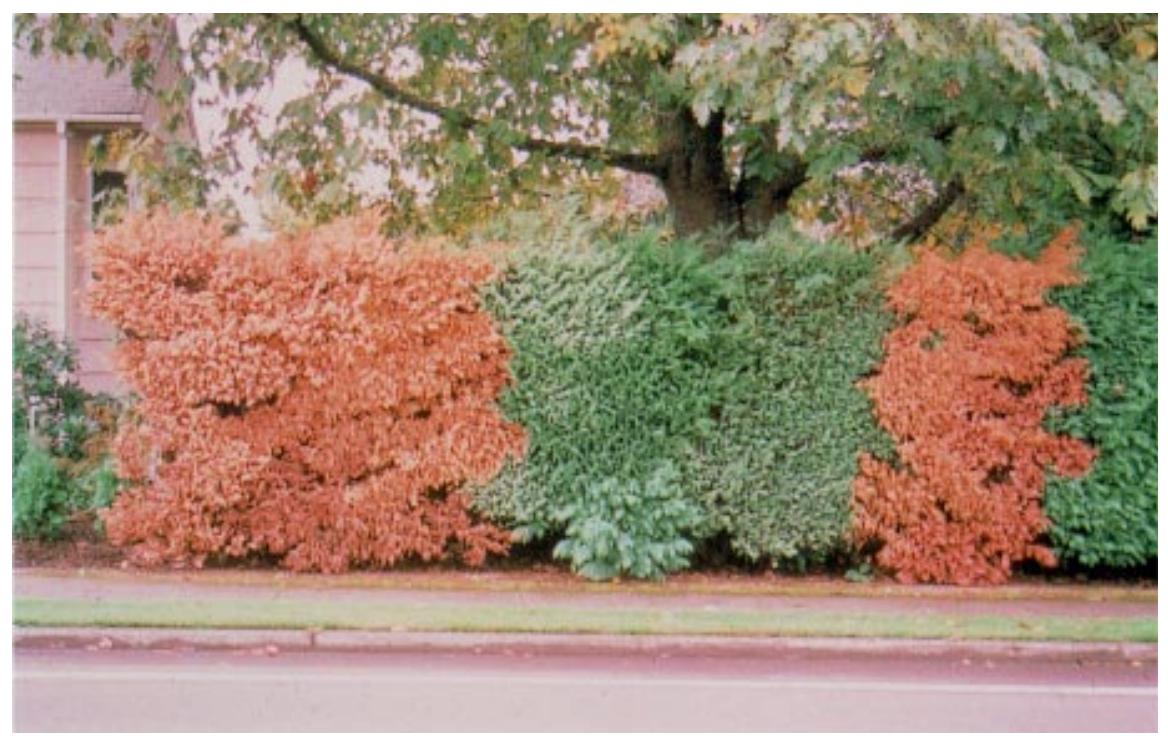

Fig. 7. Port-Orford-cedar hedgerow in Corvallis, Oregon, killed by Phytophthora lateralis.

the ornamental trade (16). At that time, John Boyce of the Forest Service recognized the aggressiveness of the pathogen and the threat it posed to POC. It was only in 1942, however, that the fungus was named (14). Ultimately $P$. lateralis destroyed the multi-million-dollar ornamental cedar industry, and it continues to spread and kill POC in hedgerows and landscape trees along the West Coast (Fig. 7). In 1952, P. lateralis was first reported in the native POC range (13), apparently introduced in infested soil with rhododendrons or other nonhost plants from an infested nursery. Initially, cedar mortality was blamed on Phloeosinus bark beetles, but the cedar beetle is invariably secondary. Within a few years, dead cedars appeared throughout the lowland forests of southwest Oregon. Spread into the mountains was slower, but as road building and timber harvest accelerated in the 1960s and 1970s, P. lateralis followed (Fig. 8).

Zoospores initiate infection in the fine roots, and hyphae grow up the roots in the inner bark, killing the roots as they advance. Trees are colonized rapidly, with the advancing margin of red-brown necrotic phloem extending $50 \mathrm{~cm}$ or more aboveground before foliage begins to dry and trees are colonized by secondary fungi and bark beetles (Fig. 9). Seedlings are killed within weeks of infection, and large forest trees are usually dead within a year of first crown symptoms.

$P$. lateralis persists in roots and root fragments for years after the tree is killed, but populations in the soil are very low $(<2$ propagules per gram), and it cannot be recovered by normal soil dilution proce-

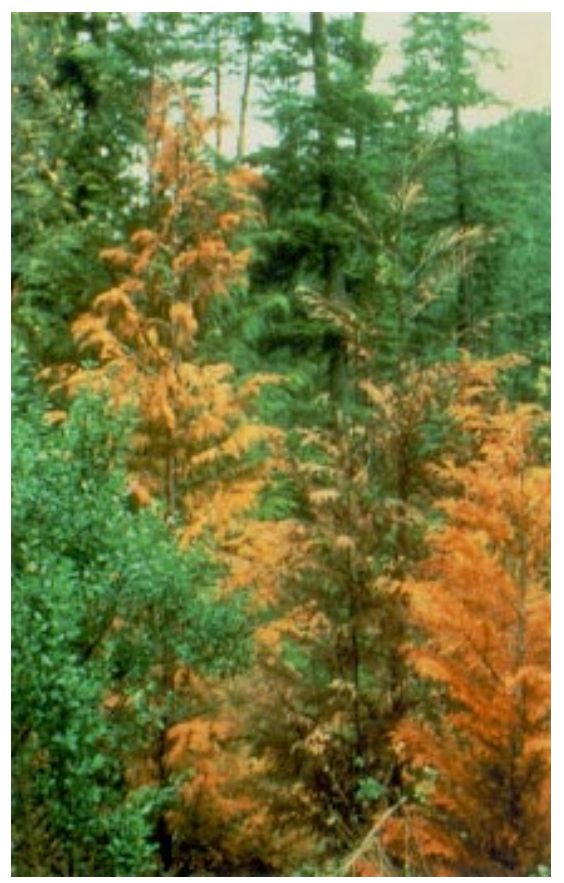

Fig. 8. Young Port-Orford-cedar killed by Phytophthora lateralis below a road on the Siskiyou National Forest, Oregon. 
dures (P. Tsao, Report to USDA Forest Service, San Francisco, CA). Baiting of the organic fraction of infested soil using cedar foliage is successful, however (12). In buried pot tests, $P$. lateralis was recovered at low frequency after 7 years, although it dies in a few days in infected roots exposed to the sun on the soil surface (3).

\section{Spread, Intensification, and Impact}

The road system in cedar country is largely infested and provides the principal pathway for disease spread. POC regener-

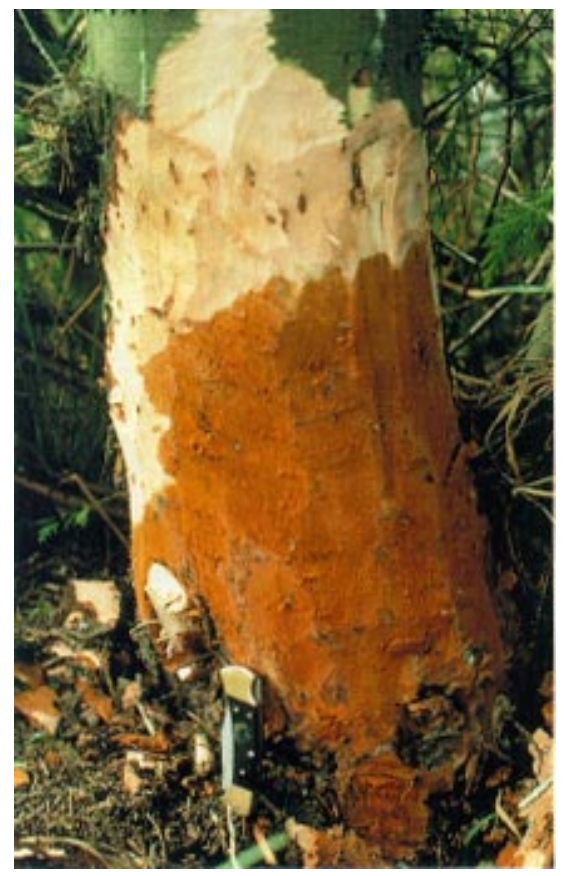

Fig. 9. Necrotic lesion caused by Phytophthora lateralis at the base of a PortOrford-cedar. Note the distinct margin between living and dead inner bark tissues. ates prolifically in disturbed soil and is especially abundant and vulnerable immediately adjacent to roads (Fig. 10). Four half-mile stretches of forest road, first infested in the 1950s, were surveyed for root disease in 1986 and then again in 1993 ("Roadside Surveys for Port-Orford-Cedar Root Disease." E. Hansen, M. Wilson, and D. Zobel. Report to the Siskiyou National Forest. 14 February 1994). Cedars were still most abundant near the roads in all areas, but mortality continues and inoculum from these roadside trees has spread further along the roads as well as downslope. The pathogen is now present across the landscape below the roads (Fig. 11).

The situation along streams is even more critical. Essentially all POC growing with their roots in contact with normal winter high water flows are killed within a few years of introduction of the pathogen to the stream (Fig. 12). Mortality of cedars growing away from streams depends on the frequency and height of winter flood events. In a 1993 survey of three infested streams, mortality of larger POC (>12.5 $\mathrm{cm}$ diameter at breast height) growing within $3 \mathrm{~m}$ of the streams ranged from 65 to $92 \%$ ("Stream Surveys for Port-Orford Cedar Root Disease." E. M. Hansen. Re-

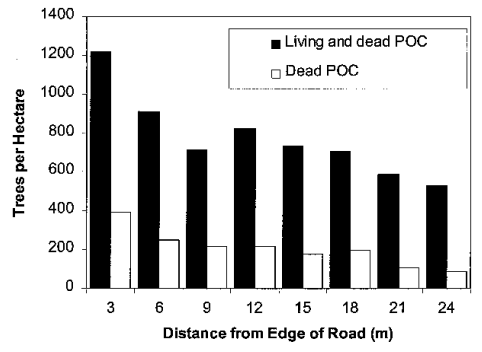

Fig. 11. Abundance and mortality of Port-Orford-cedar downslope from four infested roads in southwestern Oregon.

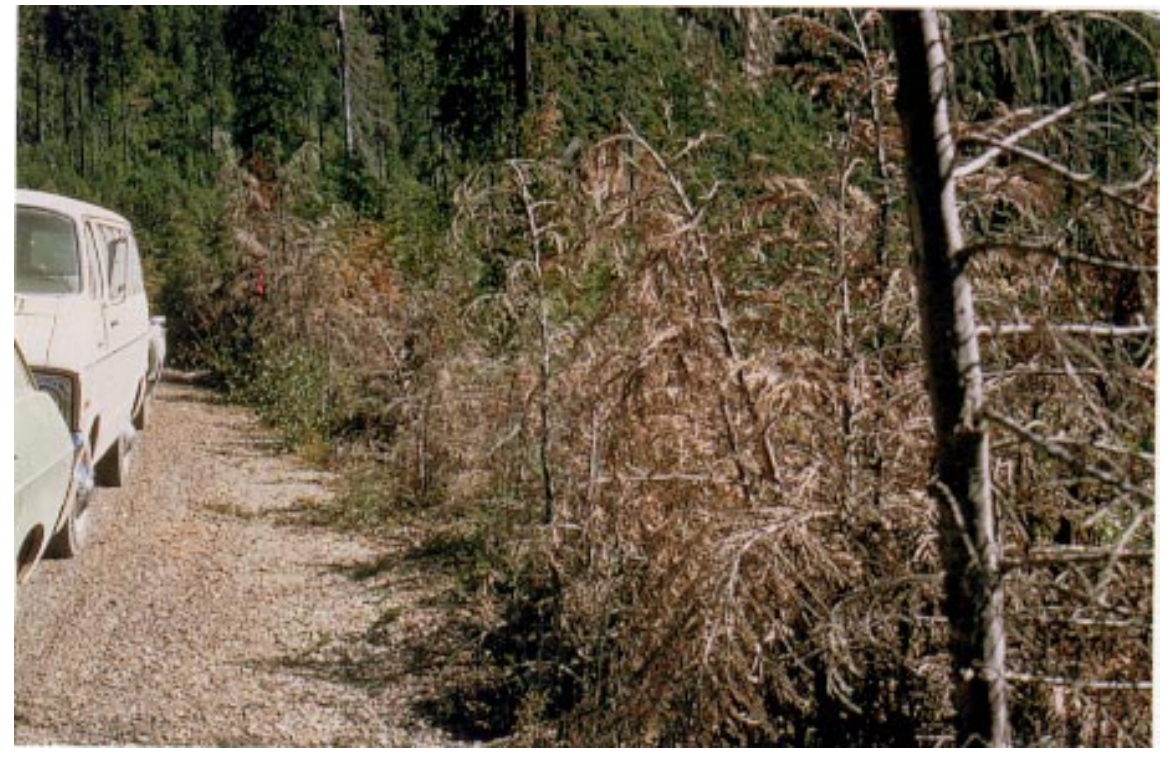

Fig. 10. Port-Orford-cedar, killed by Phytophthora lateralis, adjacent to a road on the Siskiyou National Forest, Oregon. port to the Siskiyou National Forest. 31 December 1993) (Fig. 13). The impact of POC mortality on riparian ecology depends on community structure and stream geomorphology. On ultramafic soils, POC may be the only riparian tree species. Its loss may have an immediate and drastic effect on stream ecology. Furthermore, in all but the northern part of POC's range, where higher levels of precipitation allow POC to grow farther from moving water, most or even all of the cedar may be restricted to seepages and the riparian zone.

To date, POC has not been extirpated from any portion of its range, and the species is thought to be in no danger of extinction. POC regenerates prolifically from a relatively young age and is found in a diverse array of habitats. Even in areas of long-standing mortality, many trees escape infection because local topography provides protection from a soil- and waterborne pathogen. There is no reason for complacency, however. Cedar has been drastically reduced or eliminated from miles of riparian environments and from sensitive wetlands, habitats where its ecological contributions are perhaps most critical. The size and age distribution of cedar has shifted as a result of disease and harvest. In many areas, large old trees are gone, with only smaller, young trees surviving. $P$. lateralis has been introduced into most parts of the POC range, including isolated populations separated by many miles from the main range of the tree and into some of the large federally protected and roadless wilderness areas. Once introduced, there is no practical means to eradicate the pathogen, and there are fewer and fewer large, disease-free watersheds.

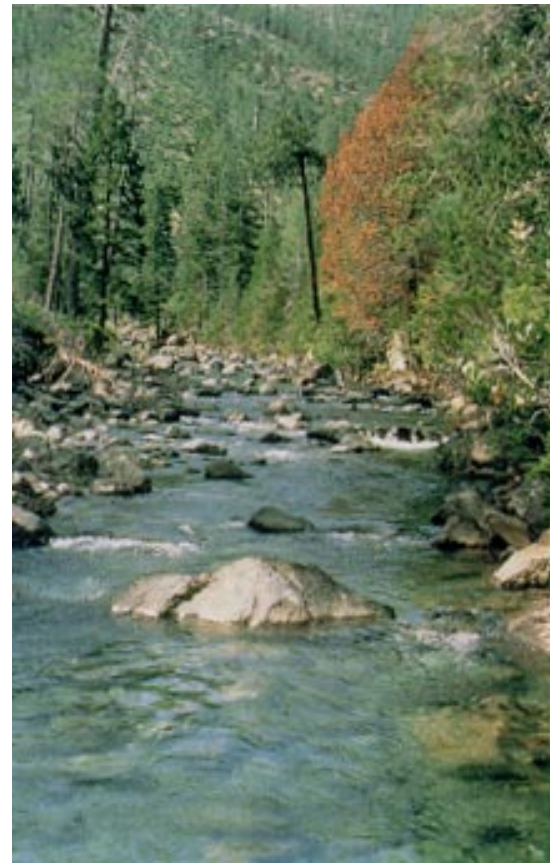

Fig. 12. Port-Orford-cedar, killed by Phytophthora lateralis, adjacent to a stream in northern California. 


\section{Disease Management}

The first substantial, coordinated, and sustained initiative to protect POC was instigated in 1985, not by the Forest Service but by the environmental community. Their challenge led to a "POC Action Plan." An early product of the plan was "POC Management Guidelines" that spelled out a risk evaluation procedure and listed appropriate mitigation measures to be implemented whenever forest operations threatened cedar resources. A POC coordinating committee with Forest Service, and more recently, Bureau of Land Management, representatives from Oregon and California was formed to promote and

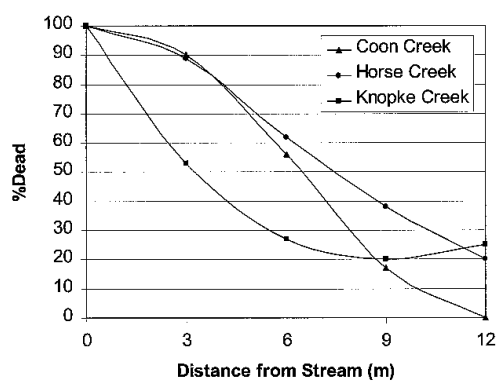

Fig. 13. Number of Port-Orford-cedar trees pole-sized and larger $(>12 \mathrm{~cm})$ and percent mortality at intervals along transects perpendicular to streams on the Gasquet District, Six Rivers National Forest, California.
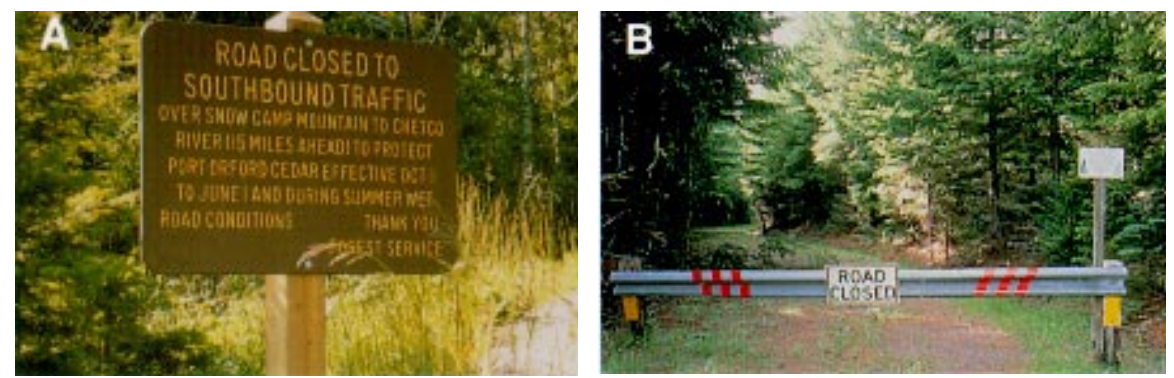

Fig. 14. Road closures are an important tool to stop the spread of Phytophthora lateralis. (A) One-way traffic (from healthy to infested areas) during the wet season (Chetco District, Siskiyou National Forest, OR). (B) Semipermanent closure of a spur road that enters a disease-free area.

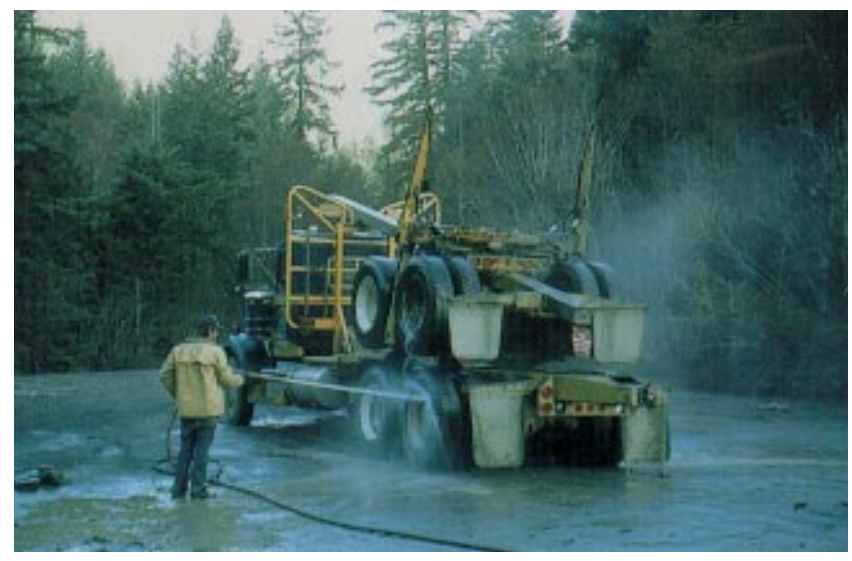

Fig. 15. Washing a log truck to remove inoculum of Phytophthora lateralis.

implement the program. The POC Action Plan has now been terminated, but the POC program continues as an integral part agency operations.

A number of techniques are currently A the federal agencies to minimize spread and intensification of

- Permanent and wet-season road closures

- Confining harvesting, road maintenance, and other activities involving heavy equipment to the summer dry season

- Washing vehicles before they enter uninfested areas

- Removing POC from high-risk roadside areas (sanitation)

- Elevating and paving road surfaces from cedar growing areas

- Using only pathogen-free water for dust abatement and fire fighting

Growing POC on sites unfavorable roads, convex slopes, etc.)

- Wide spacing of surviving POC during thinning in infested areas

- Educating forest users about the risks

- Regulating harvest of POC timber and boughs to reduce chances of spread of the pathogen on feet and equipment

(2)


abundance in the disturbed soil adjacent to the road; but more controversially, old growth cedar trees adjacent to roads in sensitive areas and along streams have also been removed.

All disease management efforts on federal lands are subject to a monitoring program. The goal of POC monitoring is to accumulate information about the effectiveness of various mitigation strategies. Unfortunately, most of the information ing (e.g., was the gate really locked?) and is not helpful in determining what works and what doesn't.

\section{Host Resistance to Phytophthora lateralis}

Since the demonstration of heritable resistance to $P$. lateralis (4), the POC resistance program has slowly gained momentum. Individual resistant trees have stood in intimate contact with the pathogen for 15 and more years. We have learned much tive propagation of POC. Recently, a range-wide collection of half-sib POC seedlings from 339 parent trees was tested for resistance using separate stem and root tests. Parent trees had not been exposed to P. lateralis; there was no prior selection for resistance. Richard Sniezko from the Forest Service Dorena Tree Improvement Center calculated family mean resistance heritabilities. They were surprisingly high, 0.21 and 0.91 for stem and root resistance tests, respectively. The family correlation gathered amounts to compliance monitorabout screening for resistance and vegeta-

between tests was low (0.15), suggesting the possibility of independently inherited resistance mechanisms.

The earliest replicated outplanting of trees selected at Oregon State University for resistance to $P$. lateralis is now in its tenth year (Fig. 17). Mortality was high for all families in the first year after planting, but after that, the rate of disease increase for resistant and susceptible families diverged. Surviving trees from several of these families were tested for resistance with a stem dip test. The cut ends of branches removed from each tree were immersed in a zoospore suspension, and the subsequent rate of growth of the pathogen up the branch was measured (Fig. 18, Table 2). Families with better survival rates had lower stem dip lesion scores. In the first systematic effort to identify resistant individuals in the forest, the Forest Service selected nearly 200 surviving cedar trees in locales where most other cedars had been killed. These were tested with a branch lesion test, and 13 trees showed resistance comparable to the best trees previously identified, whereas others were susceptible. An outplanting trial was initiated in 1993 with seedlings from openpollinated seed from 28 of these trees. After five growing seasons, nearly $50 \%$ of the seedlings from the best family survived, compared with $13 \%$ for the worst. Again, most of the mortality occurred in the first year after planting. Twelve of these 28 parent trees and their progeny have now been exposed in a series of four

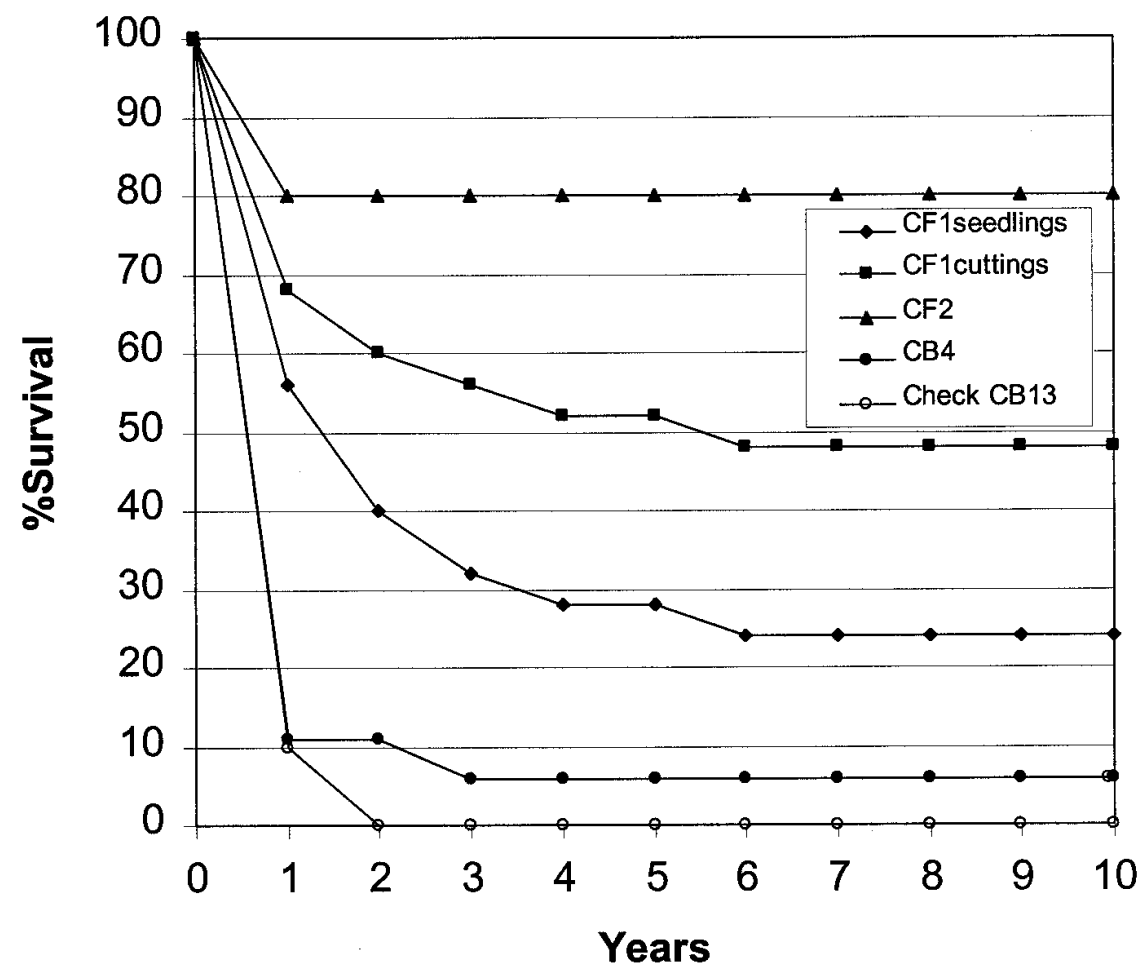

Fig. 17. Ten-year survival of seedlings (or cuttings) of four parent Port-Orford-cedar trees on an infested site at the Oregon State University Botany Farm. CF 1 and CF 2 are resistant trees, and $C B 4$ and $C B 13$ are susceptible. different resistance tests involving both root and stem inoculations. The same families (510015 from the Gasquet District, Six Rivers NF, and 118801 from the Gold Beach District, Siskiyou NF) ranked at or near the top in all tests.

The Forest Service and the Bureau of Land Management (BLM), in cooperation with Oregon State University, have now initiated a systematic program to select resistant individuals from the forest, conserve resistant families, and develop a breeding program to enhance resistance. Over 7,000 candidate trees selected along infested roads have been screened for resistance using the stem dip lesion test, and the best $10 \%$ have been vegetatively propagated and are being held in a BLM seed orchard and at the Forest Service Dorena Genetic Resource Center in a containerized seed orchard. Screening and field testing continues, and the first seedling progeny from controlled crosses are being tested. Fortunately, POC is very amenable to breeding efforts. Clones are easily established by rooting cuttings, and flowering can be induced on trees as young as 1 year. Planning continues for deployment of first generation resistant material in the forest in less than 10 years, and for breeding POC to improve the level of resistance.

Resistance to $P$. lateralis offers the best hope yet of reestablishing POC in areas where the pathogen is already established. The long-term success of the resistance strategy remains uncertain, however, given the great difference in generation times between host and pathogen, the apparent juvenile susceptibility of even the most

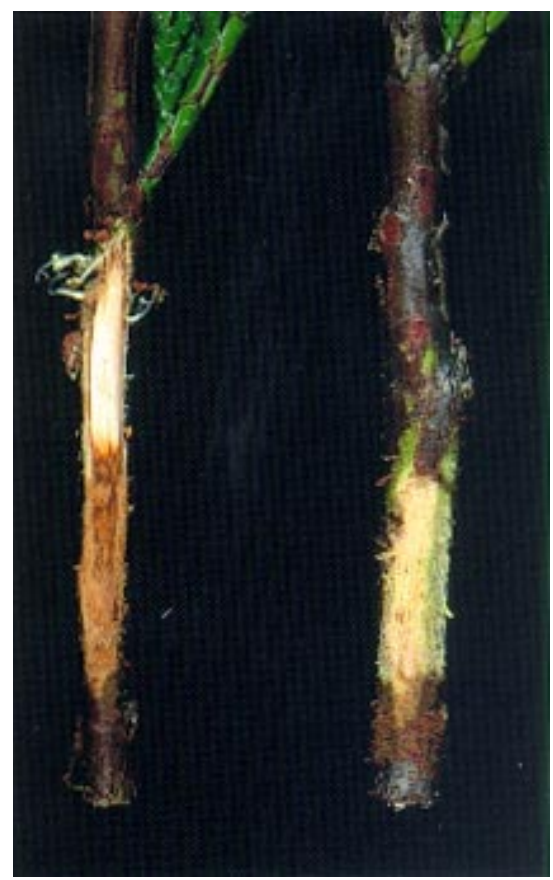

Fig. 18. Resistant (right) and susceptible (left) reactions of Port-Orford-cedar branches exposed to Phytophthora lateralis in the stem dip resistance test. 
Table 2. Ten-year field survival (Oregon State University Botany Farm) and resistance test score (stem dip test) for three families of Port-Orford-cedar selected for resistance (CF1, CF2, CB1) and three unselected families

\begin{tabular}{lccl}
\hline Parent tree & Number planted & Alive 1999 $(\%)$ & Stem dip score $(\mathbf{m m})$ \\
\hline CF 1 cuttings & 25 & 48 & $18.1(11,12-22)^{* a}$ \\
CF 1 seedlings & 20 & 24 & $21.3(6,11-32)$ \\
CF 2 & 20 & 80 & $25.2(15,14-48)$ \\
CB 1 & 20 & 45 & $19.4(8,11-38)$ \\
CB 2 & 20 & 0 & $\ldots$ \\
CB 4 & 18 & 6 & $45(1)$ \\
CB 5 & 20 & 0 & $\ldots$ \\
\hline
\end{tabular}

a $*=$ number of trees tested and range of scores.

resistant trees, and the relatively brief experience from our few outplanting trials. It will be necessary to develop supplemental protection for newly planted seedlings, perhaps using biological control agents, to identify, select, and breed for a variety of resistance mechanisms; to deploy resistant trees intelligently to minimize the risks from new races of the pathogen should they arise while maintaining the genetic diversity of the cedar population; and to continue efforts to reduce inoculum loads throughout the range of POC.

It must be emphasized that the resistance program alone offers no protection for surviving stands of POC. It will be hundreds of years before resistant seedlings can grow to reclaim the roles of large oldgrowth POC in the ecosystem. Efforts to halt transport of the pathogen into uninfested watersheds and to generally reduce inoculum pressure must be redoubled and sustained.

\section{Legal Challenges}

In 1985, regions 5 and 6 of the Forest Service convened a consensus group in response to concerns voiced by various conservation organizations regarding the decline of POC in the national forests. The group's purpose was to develop strategies and proposals for a program to halt the spread of $P$. lateralis and protect POC. It included representatives from the environmental community, the timber industry, academia, and the Forest Service. The draft consensus report was submitted to the Regional Foresters in 1986 and served as the basis for a proposed Action Plan drafted by a Forest Service POC coordinating group. The Interregional (California and Oregon) Port-Orford-cedar Action Plan was formally implemented in 1988 and guided cedar management by federal agencies until 1997.

The Action Plan did not provide for public review through the National Environmental Policy Act (NEPA) process, however. Concerns of conservation groups culminated in a lawsuit to force the Forest Service and BLM to prepare an environmental impact statement (EIS) and rangewide plan for the management of POC, in the manner of the EIS prepared for Pacific yew, and to subject the Action Plan to NEPA review. In 1998, the Ninth Circuit Court of Appeals ruled on the 1995 suit, declaring that the Forest Service and BLM were not required to prepare an EIS for the management of POC. But the court also found that the agencies may no longer shield their POC programs from NEPA review and that site-specific environmental documents could no longer be based on the broader POC program when the program itself has not been subjected to NEPA procedures. Subsequent project-by-project lawsuits are primarily challenging the efficacy of the agencies' disease control measures and the failure to disclose the underlying environmental data forming the basis for the POC program.

The Mining Law of 1872 is a highly political and legalistic complicating factor in many areas where cedar grows. Rooted in the traditions of the "Old West," the Mining Law gives individuals and corporations the right to enter public lands for mineral exploration, and upon "discovery" of a valuable mineral, to extract that mineral. Where there has been "discovery," National Forest and BLM land can be purchased for $\$ 5.00$ or $\$ 2.50$ per acre. The Department of the Interior has responsibility to validate claims of valuable minerals, and the Forest Service has the authority to regulate access to mining claims in order to protect the National Forests. However, even in designated wilderness areas, motorized access to patented and unpatented mining claims, with a high potential to spread the root disease, has been permitted. Attempts by federal agencies to regulate mining on federal lands are often challenged by the miners as infringement on their 1872 rights, and by environmental organizations as inadequate to meet agency obligations to protect natural resources, such as POC.

As a case in point, the Kalmiopsis Wilderness Area in southwestern Oregon should have remained a large disease-free refuge for POC, but the pathogen was introduced into the wilderness watershed in two areas. The probable causes for one introduction are activities associated with mining, facilitated by motorized access to wilderness claims. The other introduction occurred when the pathogen spread downslope from logging units outside the wilderness, an example of the importance of protecting entire watersheds, not just discrete stands of cedar. Solutions to the continued spread of the root disease into sensitive uninfected areas will have to come from many directions: the managing agencies, the courts, and/or Congress.

\section{Acknowledgment}

We thank Kathy Merrifield for the artwork in Figure 6.

\section{Literature Cited}

1. DeNitto, G. A., and Kliejunas, J. T. 1991 First report of Phytophthora lateralis on $\mathrm{Pa}-$ cific yew. Plant Dis. 75:968.

2. Erwin, D. C., and Ribeiro, O. K. 1996. Phytophthora Diseases Worldwide. American Phytopathological Society, St. Paul, MN.

3. Hansen, E. M., and Hamm, P. B. 1996. Survival of Phytophthora lateralis in infected roots of Port Orford cedar. Plant Dis. 80:1075-1078.

4. Hansen, E. M., Hamm, P. B., and Roth, L. F. 1989. Testing Port-Orford-cedar for resistance to Phytophthora. Plant Dis. 73:791-794.

5. Hansen, E. M., Streito, J.-C., and Delatour, C. 1999. First confirmation of Phytophthora lateralis in Europe. Plant Dis. 83:587.

6. Hartzell, H., Jr. 1991. The Yew Tree: A Thousand Whispers. Hulogisi Printing, Eugene, OR.

7. Imper, D. K., and Zobel, D. B. 1983. Soils and foliar nutrient analysis of Chamaecyparis lawsoniana and Thuja plicata in southwestern Oregon. Can. J. For. Res. 13:1219-1227.

8. Jimerson, T. M., and Creasy, R. M. 1997. Port-Orford cedar plant associations in Northern California. Proc. Conf. Siskiyou Ecol., 1st. J. K. Beigel, E. S. Jules, and B. Snitkin, eds. Siskiyou Regional Education Project, Cave Junction, OR

9. Jimerson, T. M., Hoover, L. D., McGee, E. A., DeNitto, G., Creasy, R. M., and Daniel, S. L. 1995. A Field Guide to Serpentine Plant Associations and Sensitive Plants in Northwestern California. Forest Service, Pacific Southwest Region, R5-ECOL-TP-006, 1995.

10. Murray, M. S., and Hansen, E. M. 1997 Susceptibility of Pacific yew to Phytophthora lateralis. Plant Dis. 81:1400-1404.

11. Nicolaou, K. C., Yang, Z., Liu, J. J., Ueno, H., Nantermet, P. G., Guy, R. K., Claiborne, C. F., Renaud, J., Couladouros, E. A., Paulvannan, K., and Sorenson, E. J. 1994. Total synthesis of taxol. Nature 367:630-634

12. Ostrofsky, W. D., Pratt, R. G., and Roth, L. F. 1977. Detection of Phytophthora lateralis in soil organic matter and factors that affect its survival. Phytopathology 67:79-84.

13. Roth, L. F., Trione, E. J., and Ruhmann, W. H. 1957. Phytophthora induced root rot of native Port-Orford-cedar. J. For. 1957. 55:294-298.

14. Tucker, C. M., and Milbrath, J. A. 1942. Root rot of Chamaecyparis caused by a species of Phytophthora. Mycologia 34:94-103.

15. Wani, M. C., Taylor, H. L., Wall, M. E., Coggon, P., and McPhail, A. T. 1971. Plant antitumor agents. VI. The isolation and structure of taxol, a novel antileukemic and antitumor agent from Taxus brevifolia. J. Am. Chem. Soc. 93:2325-2327.

16. Zobel, D. B., Roth, L. F., and Hawk, G. M. 1985. Ecology, Pathology, and Management of Port-Orford-cedar (Chamaecyparis lawsoniana). U.S. Dep. Agric. For. Serv. Gen. Tech. Rep. PNW-184. 
The national forests and Bureau of Land Management (BLM) districts where Port-Orford-cedar (POC) grows are mandated by the Northwest Forest Plan to practice ecosystem management on the lands they administer. Ecosystem management is defined as "the careful, informed, and integrated use of ecological principles at various scales to produce, restore, and sustain ecosystem integrity and provide desired conditions, uses, products, values, and services over the long term." It differs from more traditional forest management approaches in its emphasis on a more holistic, systems-oriented, and ecologically sensitive management philosophy, and in the stress it places on overall ecosystem sustainability.

The federal agencies responsible for managing POC recognize it as a unique and ecologically valuable tree species. Many of the areas where POC is most numerous are within designated late successional and riparian reserves, where meeting wildlife habitat needs is a paramount objective. POC is the primary, and often the only, tree species that grows large on the many ultramafic soils of the region. Loss of POC in such areas can greatly degrade habitat, especially for wildlife species that prefer or require forest stands with old-growth characteristics. Also, POC plays an essential role in riparian zones irrespective of soil type. It provides necessary large-tree structure, cover, and shade, as well as superior, longlasting down wood that enhances fish habitat. Its loss in extensive portions of riparian zones can be catastrophic. Federal managers are extremely concerned about the effects of the nonnative root disease on POC populations, as well as the detrimental impact that extensive disease-caused cedar mortality may have on important ecological functions. When dealing with an introduced disease, use of a particularly aggressive management strategy seems consistent with an ecosystem management approach. Federal managers are committed to integrating strategies for POC management into environmental analyses and project planning for all areas that support POC on federal lands, managing the species as a major component of forest stands in the appropriate plant associations and using the best possible practices identified from experience and research to prevent or reduce the spread of $P$. lateralis.

A number of techniques (outlined in the text) are being used to minimize the spread and intensification of POC root disease. Federal managers face a number of challenges in implementing these strategies on public lands. The most significant involve:

- Road closures: Since the major means of spreading P. lateralis over long distances is infested soil carried by vehicles along roads, most efforts to minimize spread are concentrated on roads. Road management is difficult, controversial, and often very expensive. Obviously, the most effective treatments to minimize spread of the pathogen into uninfested areas involve permanent road closures and avoiding construction of new roads. The federal agencies use these techniques whenever they deem them possible. On the other hand, many existing roads cannot be closed permanently, and other techniques must be used. Many roads are kept open for public and agency access and for legal reasons. The BLM, in particular, finds closing any roads extremely difficult because the lands that it administers occur in checkerboard patterns with privately owned lands, and roads are jointly owned. Reciprocal agreements that govern use of these roads prevent the agency from denying access to the other landowners. Use of temporary road closure with gates or barricades is an alternative to permanent closure. Temporary closures require considerable attention to ensure that they are indeed in place when they need to be (during wet periods at any time of year) and that they are not broached. Since the roads exist beyond the closure, thoughtless or uncaring people have found ways around the closures or have actually destroyed gates or other structures. Federal managers agree that placement and strength of barriers are important considerations in use of temporary closures, as is constant vigilance.

- Planning: Long-term planning at a landscape level is an integral part of ecosystem management and seems especially important in any effort to manage a disease such as POC root disease. On federal lands, obstacles to effective long-term planning include past lack of knowledge of location and extent of infested and uninfested stands, lack of information on disease spread, a tradition of management on individual sites rather than landscapes, and problems with coordination, especially between management units. The federal agencies are working hard to overcome planning difficulties. POC mapping has been done on all Forest Service lands and is nearing completion on lands administered by the BLM. Ultimately, they plan to have all inventory information for both agencies on a common geographic information system accessible to all. A system for constantly updating information on location and spread of disease that will interface with the mapping has been developed and is being refined and improved. Both agencies have hired full-time POC coordinators, and cooperation has greatly improved. Risk analyses with the goal of prioritizing management treatments for large areas based on known occurrence of disease and information on roads and water courses are becoming standard, and management strategies are being planned on 5-year rather than 1-year time frames.

- Effectiveness of sanitation treatments: Roadside sanitation treatments are increasingly being used as parts of POC root disease management strategies. There are two kinds of objectives for sanitation treatments. They can be aimed either at preventing or reducing new infections along roads in currently uninfested areas or at eliminating or minimizing the amount of inoculum available for transport from already infested roadsides to uninfested areas. With either objective, the key feature of a sanitation treatment is creating a zone along roads where live POC roots are absent. The idea is to kill all cedars, by cutting or girdling, within the sphere of influence of the road. This usually involves a strip 25 feet above a particular road or to the top of the cutbank and 25 to 50 feet below the road. The sanitation approach has been recommended for some time by researchers and in theory appears to be a good one. However, its effectiveness has not been definitively established. Sanitation treatments are expensive and usually require retreatment after several years to remain POC-free. Attempts have been made to monitor effectiveness of sanitation treatments by simply observing stands surrounding treatment areas and trying to determine whether there are increases or decreases in disease spread. Federal managers now recognize, however, that only a sample-based monitoring approach that actually measures occurrence and distribution of inoculum over time in treatment areas can really provide the data necessary to judge sanitation efficacy. In the last 2 years, a monitoring effort that uses POC seedlings as baits arranged in transects across treated road sections has been instituted on a large sample of sanitized road sections. Preliminary results suggest that sanitation does indeed result in decrease of inoculum over time when done along infested roadsides.

- Public awareness and participation: The federal agencies have found that keeping all sectors of the public educated, informed, and when possible involved in POC root disease management strategies is a difficult task and one that often resembles a balancing act. Some sectors of the public are very aware of POC root disease and worried about its ramifications. Other sectors are not necessarily concerned about the disease but have strong negative feelings about some of the activities 
done in the name of disease management. Many people have no idea of the significance of the disease and may inadvertently aid its spread due to lack of understanding. Environmental groups were instrumental in developing awareness of the seriousness of the disease and the importance of managing it. But now some of the same groups actively oppose agency management strategies in the courts because they do not believe that the techniques being employed will be effective. Often they believe that only exclusion or permanent road closure is worthwhile. Other user groups actively oppose all road closures.

- Funding: Funding for POC root disease management efforts has been maintained at a reasonably high level for the past few years by both the Forest Service and the BLM. A considerable proportion of root disease management support has involved national forest health protection funds from the Washington office of the Forest Service. To qualify for such funding, local managers must apply annually and compete against other proposed disease management funding projects from throughout the country. Agency managers are worried about the dependability of future POC root disease management funding, especially in view of the possibility of overall budget declines. Very little disease management funding is generated locally from timber harvest.

POC is an important and ecologically valuable component of forests in southwestern Oregon and northwestern California. Managing POC root disease where it occurs and reducing the likelihood of its spread into new localities are both critical and challenging. Successful management can only be accomplished by continuing to gain knowledge of the pathogen and its biology and using that knowledge in an integrated approach across all scales from the microsite to the landscape and, finally, to the entire range of the host.

\title{
Predictability Begets Optimism: A Conservation Perspective on Port-Orford-Cedar and Phytophthora lateralis
}

\author{
Barbara Ullian and Erik S. Jules
}

The elegant adaptations of Port-Orford-cedar (POC) to riparian and wetland environments in southwestern Oregon and northern California make it an ecologically important component of these critical habitats. POC had few biotic enemies until the introduction of the fatal root pathogen, Phytophthora lateralis, into the cedar's native range 48 years ago. Unlike other cases in which nonnative pathogens have all but eliminated the functional role of the host trees, there are still large, uninfected areas of POC remaining on public lands. These provide a unique opportunity for conservation, but their numbers are being seriously eroded by the continued spread of the root disease, making it urgent that the most effective measures to prevent further spread into remaining uninfected areas be implemented.

Because $P$. lateralis is solely soil- and water-borne, and does not produce air-borne spores, we have reason to think that the disease can be managed effectively. Quite simply, P. lateralis is a highly predictable organism: streams and roads are its principal pathways, and humans and their vehicles and equipment are its main vectors. Exclusion, through permanent road closures and halting road construction into uninfected areas, is the best strategy for maintaining healthy populations of POC. Unfortunately, managers of affected public lands are not making the hard decisions necessary to protect the remaining disease-free watersheds.

In the early part of this decade, the federal agencies had as their primary concern the threat to "commercial production" of POC by the root disease. With a few exceptions, the ecological role of POC in its various habitats was unknown or ignored by both the agencies and the public. As observations by ecologists and hydrologists were interjected into this vacuum the emphasis of the debate over the loss of POC began to change. The species' ecological values now also receive attention.

Observations thus far suggest that the role of POC is irreplaceable in many habitats. POC in riparian areas helps to shade streams, and to stabilize their banks, during high winter flows. At the end of its long life, fallen onto floodplain surfaces or in the streams it once shaded, POC's large trunk with its decay-resistant wood provides long-lasting and diverse habitat for salmonid fish and other aquatic life. As well, POC can act as an important channel-forming agent when it interacts with the stream.

POC is also of great importance on the globally unique, botanically rich area of ultramafic soils in southwestern Oregon and northwestern California. Here, the cedar is often the only large conifer in riparian areas and is commonly found in association with many rare plant species. By recycling calcium onto the surface soil, POC may help improve soil fertility, an important quality in harsh ultramafic environments. Studies underway in northern California have found POC to be a component of more than 34 plant associations. Therefore, the loss or significant decline of POC from the introduction of $P$. lateralis has the potential to affect biodiversity in many ways.

But while the debate is more enlightened than a decade ago, one by one, with little fanfare and no accountability, previously uninfected river basins and watersheds are being irreversibly infected by the root pathogen. The spread of $P$. lateralis into large areas of our national forests, once thought to be low-risk, is happening despite disease control programs on federal lands described as aggressive and/or multifaceted. The impetus provided by the efforts of conservationists and scientists has helped garner attention for the ecological role of POC and the need for strong protective strategies. But in spite of this progress, land management decisions still favor high-risk activities such as logging, mining, cedar bough cutting, mushroom collecting, and motorized recreation over the protection of POC in uninfected watersheds and stands.

The land managing agencies' refusal to prepare a range-wide assessment and management plan for POC and to subject it to public scrutiny and challenge through a formal National Environmental Policy Act (NEPA) process has been the primary area of contention between federal land managers and conservation organizations. Left with little choice but to use hard-line tactics in an attempt to force protection of POC, the public is challenging the undocumented efficacy of the agencies' disease control program on a project-by-project basis. While administrative appeals and lawsuits are often resented, the agencies' environmental documents still seldom provide more than a perfunctory description of disease control measures and no estimate of their effectiveness.

The concern for economic losses due to P. lateralis and the lack of a progressive and optimistic plan to protect uninfected POC watersheds has led to a skewed research program initiated by federal agencies. While some funding has supported important research on the basic biology of POC and P. lateralis, and on disease incidence along streams and roads, most research is now 
devoted to finding and increasing genetic resistance to the disease. It is important to repeat the reservations noted in the main text about heritable resistance that has been found in POC; resistance does not mean immunity, but rather what appears to be an increased time to mortality after initial infection.

While the results of the genetic resistance studies may be cause for optimism for those who wish to grow POC to a merchantable size, there is little evidence suggesting that planting resistant genotypes in infected regions will ever produce the old, largediameter POC that are currently being lost to $P$. lateralis. Survivorship data of cedars over one decade, or even two, are not useful for assessing our ability to produce old trees and restore cedar populations in the face of continued inoculum load.

In addition, agencies favor disease control techniques with unknown efficacy, such as "sanitation," while often rejecting measures such as permanent road closure and moratoriums on road construction and reconstruction in watersheds containing uninfected populations of POC - this despite consensus that the latter are the most effective known disease control measures. The misleading term "sanitation" refers to the removal of healthy cedar in an effort to reduce the inoculum load. When sanitation consists of the removal of seedlings that volunteer along road shoulders or even of older cedar along major road corridors where permanent road closure is not an option, it may be justified. But when 200- to 400-year-old POC are "sanitized" along low-standard or nonessential roads in botanical and other sensitive areas, or used to mitigate for new road construction in roadless watersheds, it in essence kills the very resource the disease control measure is supposed to protect.

It has become increasingly clear that POC is an ecologically important species, that the irreversible infestation of watersheds and the resulting loss of the cedar will have significant effects on critical and sensitive ecosystems, and that the spread of the disease is predictable because it is related to human activities and the presence of flowing and standing water. The continued introduction of the root disease into uninfected watersheds, while in possession of this knowledge, is disturbing. It now remains to be seen whether the ecological value of preserving areas where Port-Orford-cedar can continue to flourish will outweigh the emphasis on motorized recreation and commercial, extractive industries on national forest and BLM lands in the narrow range of this exceptional conifer.

\section{Winning the War Against Phytophthora lateralis Everett M. Hansen}

The goal of Port-Orford-cedar (POC) management should be to halt and reverse the destruction of cedar, not just slow the rate of advance of Phytophthora lateralis. It is within our power to do just that. It will require a coordinated, range-wide strategy, but both the ends and the means are supportive of the emerging philosophy of ecosystem management in the northwestern forests and should be enthusiastically and generously supported by the federal agencies. I see four main elements to a successful program:

- Identify and give maximum protection to remaining significant disease-free watersheds: The Forest Service and BLM should take the initiative to identify the remaining uninfected watersheds and protect those that have significant cedar values and are "protectable." Our best disease management efforts remain imperfect, and we must do everything possible to ensure that the most valuable areas remain healthy. In most cases, Congressional "set-asides" are neither necessary nor appropriate. Year-round road closures are the weapon of choice, backed up by other disease mitigation measures in adjacent areas. Success will require a good faith effort from the agencies and a realistic case-by-case analysis of the value and protectability of each watershed. Some roads are simply too public to close, and we will have to hope for the best using less sure measures. There is great opportunity for useful public participation in the identification and analysis of these watersheds.

- Systematically reduce inoculum in the forest and thus reduce the risk of new infection: $P$. lateralis requires very precise conditions for infection and is very sensitive to environmental conditions, especially heat and drying (3). Indeed, the probability of successful infection is low in any specific instance. But even low-probability events become likely given enough opportunity, and opportunity abounds along the numerous roads and streams of the POC region. Cedar is its own worst enemy along roads, growing as a weed in road berms. A trace of inoculum carried as mud on a vehicle quickly increases as roadside cedars are infected and produce more spores. The more the inoculum, the greater the probability of successful spread downslope from the road, and the greater the probability of spreading the pathogen further along the road system during subsequent road use. Probabilities cannot be reduced to zero, but removal of "weed" cedar along roads will certainly help reduce the regionwide infection rate and chances of introduction to new areas.

- Identify, improve, and deploy resistant POC genotypes: Introduced pathogens succeed in large part because resistance is low in the previously unexposed host population. Building resistance to $P$. lateralis in POC populations must be an integral part of a long-term disease management strategy. No significant variation in pathogenicity or in any other character has been identified in $P$. lateralis, although further testing is necessary. The pathogen exists as a genetically simple population ( $M$. McWilliams, unpublished data) as a result of initial and recent introduction of one or a few individuals. A continuing program of research and breeding to incorporate a variety of resistance mechanisms, and careful deployment of resistant stock as it becomes available, can ensure that the tree stays ahead of changing pathogen populations.

- Constructively engage all interested parties in the effort: There are two organized interest groups committed to the protection of POC: the federal agencies and the environmental community. These two groups have been locked into adversarial roles, however. Beating $P$. lateralis will require sustained energy and a variety of ideas, as well as gates, saws, and tree breeding. The time is right to try yet again to let common sense and common interests prevail. There are many obstacles, but a new "Range-wide Assessment" of the status of POC and its management is providing new opportunities for public involvement and constructive dialog. The intricacies of federal environmental law and especially the archaic 1872 Mining Law are a challenge to both sides, but common interest suggests that a constructive way forward can be found. 


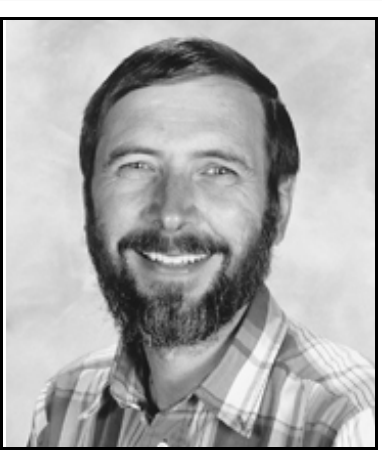

Everett Hansen

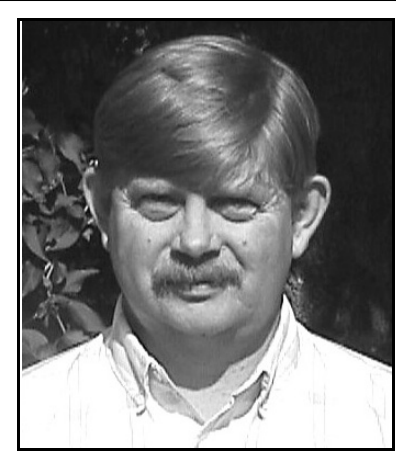

Don Goheen

Dr. Hansen is a professor of plant pathology in the Department of Botany and Plant Pathology at Oregon State University, where he teaches and conducts research in forest pathology. He has a B.S. in forestry from Oregon State University $(1968)$ and a Ph.D. in plant pathology from the University of Wisconsin (1972), where he studied with Dr. Robert F. Patton. The research interests of Dr. Hansen and his students include silviculture and disease management (laminated root rot and black stain root disease), genetics of resistance (cedar root rot and Swiss needle cast), epidemiology (Swiss needle cast and dwarf mistletoe), population biology and phylogeny (Phellinus and Phaeocryptopus species), and the ecological impact of pathogens in natural ecosystems (especially Phellinus and Phytophthora). He has worked with Port-Orford-cedar since 1975, including service with the consensus group that stimulated current Forest Service disease management efforts. He recently co-organized and directed an international conference on "Phytophthora in Forests."

Dr. Goheen is plant pathologist-entomologist with the USDA Forest Service, Southwest Oregon Forest Insect and Disease Service Center in Central Point, Oregon. He has a B.S. in forestry (1971) and a Ph.D. in plant pathology (1976) from the University of California at Berkeley. Dr. Goheen is responsible for providing federal resource managers in Southwest Oregon with technical assistance on forest pathogens and insects and ensuring that insect and disease concerns are appropriately addressed in ecosystem management planning. His areas of special interest include investigating the natural roles of pathogens and insects in Southwest Oregon forests, evaluating the effects of forest management activities, especially fire exclusion and timber harvest, on insects and pathogens, and investigating exotic

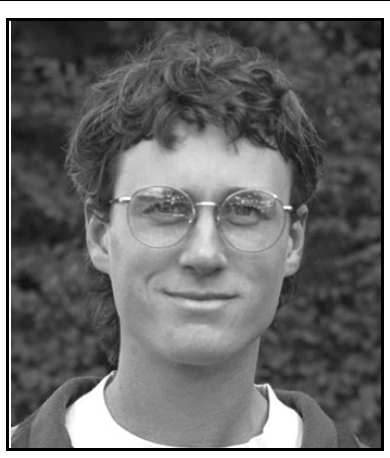

Erik S. Jules

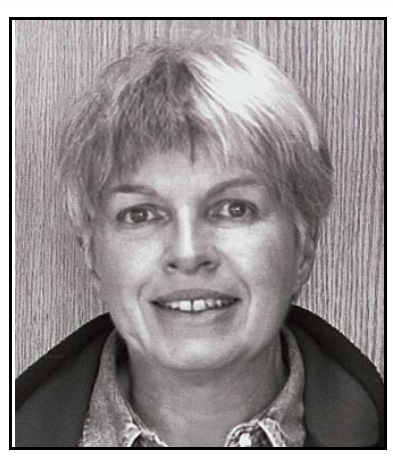

Barbara Ullian pathogens that affect Southwest Oregon trees. Dr. Goheen has worked with Port-Orford-cedar root disease since 1976.

Dr. Jules is an assistant professor in the Department of Biology at Humboldt State University. He has a B.A. in biology and philosophy from Ithaca College and an M.S. and Ph.D. in biology from the University of Michigan. Dr. Jules then held a postdoctoral position in the Department of Environmental Studies at the University of California, Santa Cruz. His teaching responsibilities at Humboldt State include courses in plant ecology and plant taxonomy. Dr. Jules' current research interests include the effects of habitat fragmentation on herbaceous plant populations and the spread of Phytophthora lateralis through the range of Port-Orford-cedar. His work on the cedar involves using dendrochronology techniques to date the mortality of cedars, and to reconstruct the historical spread of root rot down individual streams and across large landscapes.

Ms. Ullian is conservation director for the Siskiyou Regional Education Project, a grassroots nonprofit conservation organization dedicated to preserving the ecological integrity and biological diversity of the Siskiyou Mountain region of southwestern Oregon and northwestern California. The Siskiyou Project is one of the leading organizations working to protect Port-Orford-cedar and its habitat on federal lands. Ms. Ullian has studied and written extensively on the ecological values of Port-Orford-cedar and on the adverse effects of Phytophthora lateralis introduction and the functional loss of the cedar from stream and wetland ecosystems. She reviews, challenges, when necessary, or supports activities proposed by the federal land managing agencies that impact Port-Orford-cedar and is a nationally published photographer. 